
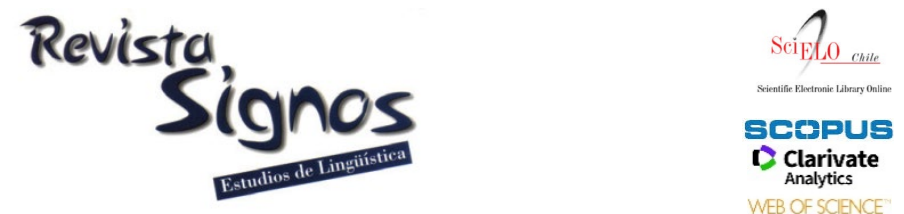

WEB OF SCIENCE

\title{
Effects of a kindergarten phonological awareness intervention on grade one reading achievement among Spanish-speaking children from low-income families
}

\author{
Efectos de un programa de intervención en conciencia Fonológica \\ en Jardin de Infantes sobre el nivel lector en primer grado en \\ niños hispanobablantes de entornos vulnerables
}

\author{
María Elsa Porta \\ CONICET, UNIVERSIDAD NACIONA \\ ARGENTINA \\ meporta@mendoza-conicet.gov.ar
}

David K. Dickinson
VANDERBILT UnIVERSITY'S PEABODY
COLLEGE
USA
david.dickinson@vanderbilt.edu

Received: 13-VII-2020 / Accepted: 14-X-2020

\section{DOI: $10.4067 /$ S0718-09342021000200409}

\begin{abstract}
There is little knowledge about the effects of kindergarten Spanish phonological awareness interventions on literacy outcomes of grade one children from vulnerable environments. To fill this gap, this study evaluates the effects of a kindergarten phonological awareness intervention on grade one literacy skills in Spanish speaking children $(N=178)$ from low-income neighborhoods in Argentina. The three-month program delivered at the beginning of kindergarten included 34 lessons focused on phoneme segmentation, categorization, and blending, and letter-sound knowledge. Using a pretest-posttest comparison-group design, measures of phonological awareness, word reading, and spelling were collected before the intervention, immediately after the intervention, and one year later when children were finishing grade one. In addition, reading comprehension was examined at the end of grade one. Results reveal that the intervention had significant effects on phonological awareness, letter-sound knowledge, word reading, spelling, and reading comprehension. These findings suggest that a systematic, phonological awareness intervention program delivered during kindergarten to native speakers of Spanish has a positive impact on their grade one literacy outcomes.
\end{abstract}

Key Words: Intervention, phonological awareness, Spanish-speaking children, spelling, reading. 


\section{Resumen}

Existe escaso conocimiento sobre los efectos de programas de intervención en conciencia fonológica sobre la lecto-escritura en primer grado en niños de habla hispana de entornos vulnerables. Este estudio evalúa los efectos de un programa de intervención en Jardín de Infantes sobre el nivel de lecto-escritura adquirido en primer grado en niños hispanohablantes $(\mathrm{N}=178)$ de entornos de bajo nivel socioeconómico de Argentina. El programa de intervención de tres meses de duración que se impartió a comienzos del Jardín de Infantes consistió en 34 lecciones focalizadas en segmentación fonémica, categorización de sonidos, síntesis de sonidos y conocimiento del nombre y sonido de las letras. Se empleó un diseño cuasi-experimental de tipo pre-post con mediciones repetidas. Se obtuvieron mediciones de conciencia fonológica, lectura de palabras y escritura antes e inmediatamente posterior a la intervención, así como también una medición de comprensión lectora al final de primer grado. Los resultados mostraron que la intervención tuvo un efecto significativo sobre la conciencia fonológica, conocimiento del nombre y sonido de las letras, lectura de palabras, escritura y comprensión lectora. Los hallazgos sugieren que una intervención sistemática en conciencia fonológica impartida durante Jardín de Infantes a niños hispanohablantes presenta un impacto positivo sobre la lecto-escritura al final del primer grado.

Palabras Clave: Intervención temprana, conciencia fonológica, niños hispanohablantes, escritura, lectura.

\section{INTRODUCTION}

Phonological awareness (PA) is the ability to recognize, identify and manipulate the phonological structures of words such as phonemes, syllables and rhymes (Ziegler \& Goswami, 2005) and has been recognized as a key predictor of reading achievement across various languages (e.g., Georgiou, Torppa, Manolitsis, Lyytinen \& Parrilla, 2012; Suggate, Reese, Lenhard \& Schneider, 2014; Rodríguez, Van Der Boer, Jiménez \& De Jong, 2015; Landerl, Freudenthaler, Mortiz, De Jong, Desrochers, Manolitsis \& Parrilla, 2019). Given its importance, the effects of phonological awareness training programs for primary school children have been examined, with significant effects found on a variety of reading measures (e.g., Ehri, Nunes, Willows, Schuster, Yaghoub-Zadeh \& Shanahan, 2001; Lonigan, Schatschneider, Westberg, 2008; Suggate, 2016). However, most of these interventions have been conducted in English, an outlier orthography (Share, 2008), which limits the development of universal theories of reading. To our knowledge, only a few number of studies (e.g., Herrera, Defior \& Lorenzo, 2007; Defior, 2008; Arancibia, Bizama \& Sáez, 2012; Meneses, Garzón, Macías, Aragüelles, Triana \& Rodríguez, 2012; Bizama, Arancibia \& Sáez, 2013; González, Cuetos, Vilar, \& Uceira, 2015; Gutiérrez \& Díez, 2017; Gónzalez, López, Cuetos \& Vilar, 2017) have examined the effects of PA interventions on Spanish-speaking monolingual children. However, none of them has examined effects of a PA intervention delivered in kindergarten on grade one word reading and reading comprehension. In principle, insights from English PA interventions could be generalized to Spanish. However, differences in the 
phonological and orthographic structures between the two languages limit the scope of these generalizations. For example, whereas English is characterized as a deep orthography because of the extent of irregularities in grapheme phoneme mapping, Spanish is characterized as a shallow orthography (Seymour, Aro \& Erskine, 2003). Whereas in English it is well established that a combination of phonemic awareness and phonics is the most effective early reading intervention (see Suggate, 2016 for a meta-analysis), little is known about the effects of such interventions among monolingual Spanish children. Moreover, orthographic variations influence the development of PA and reading; therefore, it remains to confirm whether Spanish PA training in kindergarten has a significant impact on grade one word reading and reading comprehension.

Gomes-Koban, Calet and Defior (2019: 379) note similar limitations of extrapolating insights from English reading research to Spanish:

"English and Spanish differ in many aspects, including in the transparency of the orthography (Seymour, Aro \& Erskine, 2003), prosodic features (Calet, Gutiérrez-Palma, Simpson, González-Trujillo \& Defior, 2015; Dauer, 1983), and speech production (Carreiras \& Perea, 2004). Additionally, the rate of learning to decode from print to speech differs greatly with Spanish-speaking children achieving a reading accuracy of $95 \%$ of words after the first year of learning to read, compared with 35\% for more opaque languages such as English (Caravolas, Lervåg, Defior, Seidlová-Málková \& Hulme, 2013; Caravolas, Lervåg, Mousikou, Efrim, Litavský, Onochie- Quintanilla, Salas, Schöffelová, Defior, Mikulajová, Seidlová-Málková \& Hulme; 2012; Seymour et al., 2003)."

Beyond the linguistic aspects, cultural differences, educational policies, and other environmental and political divergences prevent a direct application of findings from studies in English to Spanish, highlighting the need of evidence from Spanishspeaking contexts (Gomes-Koban et al., 2019). This paper addresses these gaps by examining the effects of a kindergarten, phonological awareness intervention on grade one reading skills among low SES, monolingual Spanish speaking children in Argentina.

\section{Theoretical framework}

\subsection{Academic outcomes in Spanish-speaking children from low socioeconomic backgrounds}

Many children in Argentina currently repeat grade two, and before 2014, when still permitted, a high percentage of children repeated grade one (United Nations Educational Scientific and Cultural Organization, 2019). Notably, this is the same period children are expected to learn to read. Most of these children are from low- 
socioeconomic homes, defined as children whose parents present low levels of education and income (Hoff, 2013). The disproportionate representation of Argentinian first and second graders from low SES failing academically is not surprising, as socio-economic background has been observed to be a strong predictor of early school failure (Borzone, Rosemberg, Diuk \& Amado, 2005; Filippetti, 2012; Davoudzadeh, McTernan \& Grimm, 2015; Wolf, Magnuson \& Kimbro, 2017). This phenomenon has been partly explained by the quantity and quality of language interactions at home (e.g., Letts, Edwards, Sinka, Schafer \& Gibbons, 2013). These differences in early linguistic exposure have implications for the development of phonological awareness because it is closely tied to early vocabulary development (Dickinson, McCabe, Anastasopoulos, Peisner-Feinberg \& Poe, 2003).

Examinations of language and literacy profiles of grade one Spanish-speaking children from low-income families reveal they have lower scores in vocabulary, language comprehension, phonological awareness, letter-name knowledge, and lettersound correspondences than children from middle class families (Borzone et al., 2005; Filippetti, 2012; Mancilla-Martinez \& Lesaux, 2011, 2017). Three comparative studies conducted in Argentina show that children from homes with low socioeconomic levels display lower scores than children from homes with middle socioeconomic levels in all phonological awareness skills assessed in kindergarten and grade one: initial sound identification, initial sound isolation and phoneme elision (Diuk, Borzone \& Ledesma, 2010; Canales \& Porta, 2016, 2018). Because linguistic abilities at school entry are highly related to later academic competencies (Suárez-Coalla, García de Castro \& Cuetos, 2013; Bowyer-Crane, Fricke, Schaefer, Lervag \& Hulme, 2017; Gutiérrez-Fresneda, Vicente-Yagüe \& Alarcón, 2020), weak phonological awareness in kindergarten may explain, at least in part, Argentinean children's struggles in the primary grades. Thus, it is essential to provide enhanced instruction on phonological awareness for children who are behind their peers at school entry.

\subsection{PA and literacy development}

Across diverse languages with relative transparent orthography, PA has been recognized as a key precursor of reading achievement (e.g., Suárez-Coalla et al., 2013; Caravolas et al., 2013, 2019; Suggate et al., 2014; Branum-Martin, Tao \& Garnaat, 2015). Further, a subset of PA, phonemic awareness, is crucial for phonemic decoding of words with regular letter-sound correspondences (Defior \& Serrano, 2011; SuárezCoalla et al., 2013; Gutiérrez \& Díez, 2015; Gutiérrez, 2016; Jasińska \& Laura-Ann, 2017). If children do not develop strong phonemic awareness skills at the end of kindergarten, it will be difficult for them to master the alphabetic principle and associate sounds with the letters that represent them (Al Otaiba, Kosanovich \& Torgesen, 2012). The alphabetic principle is the basis of decoding; therefore, children with weak PA struggle to decipher the written language code. In a study of four alphabetical languages (English, Spanish, Czech, and Slovak), phoneme awareness in 
kindergarten predicted decoding skills at the end of grade 1, which in turn predicted reading comprehension in grade 2 (Caravolas et al., 2019).

Research across languages shows that children follow the same progression of development of PA: sensitivity to syllables develops first followed by onsets and rimes and finally, phonemes (e.g., Villalón, 2008; Anthony, Williams, Durán \& Laing, 2011; Gutiérrez, et al., 2020). In Spanish, along with phoneme awareness, syllable awareness plays a significant role in reading (Herrera \& Defior, 2005; Anthony et al., 2011; Calet, Flores, Jiménez-Fernández \& Defior, 2016). However, by kindergarten, the majority of Spanish-speaking children seem to have mastered syllable awareness (Defior \& Herrera, 2003; Herrera et al., 2007; De la Calle, Aguilar \& Navarro, 2016). By contrast, phonemic awareness is the strongest early predictor of reading (Defior \& Serrano, 2011; Suárez-Coalla et al., 2013; Gutiérrez \& Díez, 2015; Gutiérrez, 2016; Jasińska \& Laura-Ann, 2017) and continues being the strongest predictor of Spanish reading and writing up to grade three (Bravo Valdivieso, Villalón \& Orellana, 2006). Altogether, results from relevant research suggest that PA should be the main focus of early literacy interventions (Foorman, Beyler, Borradaile, Coyne, Denton, Dimino, Furgeson, Hayes, Henke, Justice, Keating, Lewis, Sattar, Streke, Wagnwer \& Wissel, 2016).

\subsection{PA interventions}

There is some recent research focusing on PA interventions in monolingual Spanish-speaking populations. For example, Meneses, et al. (2012) examined the effectiveness of a PA intervention focusing on syllable and phoneme segmentation, first sound identification, rhymes, and grapheme phoneme correspondences. Twentyfive children in kindergarten and grade one participated in this study. The researchers found significant differences between pre-intervention and post-intervention performance in all the PA aspects measured, but syllable segmentation. However, the lack of a comparison group makes it hard to attribute the gains to the phonological training. Moreover, the sample size was too small. In a more rigorous design, Bizama, et al. (2013) examined the effectiveness of a kindergarten intervention focusing on segmentation of phrases, syllables, and phonemes. Forty-one kindergarteners with an average age of five years and six months participated in this study. Children in the PA intervention made larger gains on segmentation tasks than the comparison group. Arancibia et al. (2012) observed similar results in a study that included both kindergarteners and first graders. In another phonological awareness, training study for Uruguayan kindergarteners, Cuadro and Trias (2008) found that the PA intervention was more effective when training on phoneme segmentation, identification, blending, addition, deletion, and substitution was complemented with teaching of 'graphemephoneme' correspondences. Although these findings, along with others from similar studies (e.g., Rincón \& Pérez, 2009) suggest that it is possible to 
intervene effectively Spanish PA in kindergarten, they do not answer whether this intervention has a positive impact on reading skills in grade one.

To our knowledge, only a limited number of studies have examined the impact of a Spanish PA on reading. In two of them, Defior (2008) and Gutiérrez and Díez (2017), the findings revealed positive effects of grade one PA interventions on word recognition. In Defior (2008), the study used a pre-post experimental design to investigate the effects of a 20-lesson PA intervention program on typically developing first graders. The program included interactive tasks that helped children identify phonemes when reading and writing. The intervention had significant effects on word recognition and spelling at post-test and at a follow up two months after the end of the intervention. Similarly, in Cuadro and Trias (2008), the most successful intervention was the one that combined PA with grapheme phoneme correspondences. However, these effects disappeared one year later when children were finishing grade two. González, et al. (2015) also found positive effects of a PA intervention delivered in kindergarten. The experimental group outperformed the control group on writing syllables and pseudo words when they were in first grade. We are not aware of studies reporting the effects of a kindergarten phonological awareness intervention on word recognition, spelling, and reading comprehension in grade one.

PA interventions in Spanish from the past decade suggest that PA interventions support spelling, reading, and writing. This research has found positive effects on phonological awareness skills in kindergarteners and first graders (Arancibia, et al., 2012; Bizama, et al., 2013; Herrera, et al., 2007; Meneses et al., 2012), spelling for first graders (González et al., 2015), and word recognition for first graders (Defior, 2008; Gutiérrez \& Díez, 2017). However, there is still much to learn about PA in Spanish including the aspect of PA to focus, the duration and regularity of the intervention, the long-term impact on various reading measures, and the characteristics of the most effective interventions. Moreover, there is a dearth of longitudinal research considering effects of PA interventions delivered in kindergarten on grade one word reading, spelling, and reading comprehension.

Insights from PA interventions in English suggest they are more effective when implemented in preschool, kindergarten, and grade one, when letter sound correspondences are taught, when the focus is kept to one or two skills, and when the interventions are relatively brief (5 to 18 hours) (National Reading Panel, 2000; Hulme, Bowyer-Crane, Carroll, Duff \& Snowling, 2012).

Informed by this evidence, we developed a 12-week, PA intervention for low SESSpanish-speaking Argentinean kindergartens. Both short and long-term effects were examined. The intervention focused on phoneme identification, segmentation, and blending along with initial training (limited to eight letter-sound correspondences) in 
letter-sound correspondences. To minimize methodological flaws identified in prior PA interventions studies (e.g., Hawthorne effect and insufficient assurance of fidelity of treatment), we included an alternate intervention for the comparison group, scripted lessons for the interventions, and weekly recording and analyses of lessons.

In our analyses, we addressed the following research questions: What are the short and long-term effects of a kindergarten PA intervention on PA, letter-sound knowledge, word reading, spelling, and reading comprehension among Spanishspeaking Argentinean children? Specifically, are there significant differences in posttreatment outcome measures across the treatment and comparison groups? Based on prior research we hypothesized that the PA intervention delivered in kindergarten would have a significant effect on PA and letter-sound knowledge in kindergarten and on PA, reading, and spelling outcomes in grade one.

\section{Methodological framework}

\subsection{Participants}

We obtained approval from the CONICET (National Scientific and Technical Research Council) to conduct this research. The assessment began after obtaining signed agreement from the school district and informed consent from the children's primary caregiver.

Children were one hundred seventy-eight monolingual Spanish-speaking kindergarteners ( 96 were male and 82 female), from eight classes, in three state-funded schools located in low-income communities of Mendoza, Argentina (see Table 1). Children met the following criteria: 1) they had no known history of neurological problems or hearing difficulties (parental report), 2) they had not learned to read (teacher report and pre-treatment data), 3) the majority of their parents had middle- to low-academic level (according to school records, the average years of school attendance of the parents were 15 years or less, equivalent to a high school diploma or less) $-74 \%$ with low-academic level and $24 \%$ with middle-academic level, and 4 ) they were from middle $(19 \%)$ or low $(82 \%)$ socioeconomic status families (according to school records). The mean age of participating children in months, at pre-intervention, was $M=64.6(S D=4.30)$, and their mean reading level was $M=383.23(S D=5.27)$, which has a reading age equivalency to four year-olds (Woodcock \& Muñoz-Sandoval, 1996). Children's general cognitive ability, as measured with vocabulary and nonverbal reasoning, was $M=91.56(S D=14.70)$.

Three schools were selected purposefully based on the following criteria: a) neither grapheme nor phonemic instruction was introduced in the kindergarten class as part of the regular curriculum, and b) the majority of the children who attended were from low-income neighborhoods and low parental level of education. The experimental 
groups received a PA training program. Eight kindergarten teachers and their students (with school district and parental permission) from these schools voluntarily agreed to participate in the study. Four of them were assigned to the intervention condition (101 kindergarteners) and the other four to the control group (77 children) according to their availability. The control and the intervention groups were equivalent at pre-test on gender, level of parental education, socioeconomic status, and home literacy environment as revealed by $X^{2}$ tests and on age, reading level, general cognitive ability, word reading, spelling, reading comprehension, letter name-sound knowledge, and PA as revealed by one-way ANOVAS (see Table 1).

Table 1. Comparison of experimental and control groups' demographic variables using ChiSquare and age, cognitive ability and literacy variables using ANOVA.

\begin{tabular}{|c|c|c|c|c|}
\hline & Control & Experimental & $X^{2}$ & $P$ \\
\hline No. of boys & 42 & 54 & & \\
\hline \multirow[t]{2}{*}{ No. of girls } & 35 & 47 & & \\
\hline & & & 0.02 & 0.88 \\
\hline \multicolumn{5}{|l|}{ Level of parental education } \\
\hline Low & 61 & 72 & & \\
\hline Middle & 16 & 26 & & \\
\hline \multirow[t]{2}{*}{ High } & 0 & 3 & & \\
\hline & & & 3.11 & 0.21 \\
\hline \multicolumn{5}{|l|}{ Socioeconomic status } \\
\hline Low & 63 & 82 & & \\
\hline Middle & 14 & 19 & & \\
\hline \multirow[t]{2}{*}{ High } & 0 & 0 & & \\
\hline & & & 0.64 & 0.42 \\
\hline \multicolumn{5}{|l|}{ Home literacy environment } \\
\hline Low & 55 & 66 & & \\
\hline Middle & 20 & 27 & & \\
\hline \multirow[t]{3}{*}{ High } & 2 & 8 & & \\
\hline & & & 2.66 & 0.26 \\
\hline & & & $t$ & $P$ \\
\hline Mean age (months) & $64.55(4.3)$ & $64.65(4.2)$ & 0.14 & 0.88 \\
\hline Reading level (grade equivalent) & $383(5.2)$ & $383(5.3)$ & 0.94 & 0.36 \\
\hline \multicolumn{5}{|l|}{ General cognitive ability } \\
\hline Vocabulary & $9.86(3.9)$ & $9.44(3.6)$ & 0.7 & 3.61 \\
\hline Block design & $7.88(4.1)$ & $7.1(3.8)$ & 1.1 & 0.27 \\
\hline Word reading & $383.76(2.4)$ & $382.87(2.2)$ & 0.26 & 0.79 \\
\hline Spelling & $0.41(0.8)$ & $0.23(0.8)$ & 0.14 & 0.88 \\
\hline Letter-Name sound Knowledge & $3.40(0.7)$ & $3.88(0.6)$ & 0.49 & 0.62 \\
\hline Initial sound identity & $6.42(0.2)$ & $6.11(0.2)$ & 1.53 & 0.12 \\
\hline Rhyme identity & $7.18(0.2)$ & $7.06(0.2)$ & 0.40 & 0.34 \\
\hline Phoneme segmentation & $0.72(1.2)$ & $0.91(1.1)$ & 0.11 & 0.91 \\
\hline Sound blending & $452.47(1.4)$ & $451.51(1.4)$ & 0.52 & 0.60 \\
\hline Syllable and phoneme isolation & $2.83(0.2)$ & $2.65(0.2)$ & 0.62 & 0.53 \\
\hline Syllable and phoneme deletion & $2.64(0.4)$ & $2.25(0.4)$ & 0.29 & 0.77 \\
\hline
\end{tabular}




\subsection{Design}

To assess the impact of the PA training program on literacy outcomes, we used a pretest-posttest quasi-experimental comparison group design with repeated measures. Children were assessed once before the intervention and twice (at the end of kindergarten and grade one) after the intervention on PA, word reading, spelling and letter-name and sound correspondences. Reading comprehension was assessed in the second post-intervention assessment only, when children were finishing grade one.

The pretest took place at the beginning of kindergarten and lasted a month. The intervention started after the pretest and lasted three months. The first post-test took place at the end of kindergarten and the second posttest took place at the end of the following academic year, when children were finishing first grade.

Intervention. The PA training program consisted of 34 lessons of 30 minutes each, three times a week, delivered by the teacher to the whole class. The researcher offered weekly training to the teachers on how to deliver the lessons and provided scripts with description of the activities, the materials, and detailed instructions for every activity. To facilitate implementation and increase treatment fidelity, the researcher provided all materials required for the intervention lessons. During the intervention, teachers first modelled every activity to the whole class and then coached the students through individual activities using manipulative materials (e.g., moving placeholders along boxes to indicate when they heard a given sound, placing pictures inside bags).

The intervention program was an adapted version of Blachman, Ball, Black and Tangel (2000). Every lesson included three exercises focusing on phoneme segmentation (e.g., Elkonin card activities). In the task called 'Say-It-and-Move-It', children were instructed to break apart words with three and four phonemes (e.g., sol /s//o//1/, sun in English) into their individual sounds and place a button, per each sound they heard, in boxes. Variations of this activity involved placing the button in the first, second, third box, according to the position in which they heard a target sound (e.g., if the target sound was $/ 1 /$, they had to place the button in the third box when they heard the word sol). The second exercise included a linguistic game to foster one of the following abilities: initial sound isolation, rhyme awareness, sound categorization, or sound blending. To develop rhyme and initial sound categorization, the program included several oddity tasks requiring children to select a picture representing a word starting with a sound different to the initial sound of the words represented by the two other pictures. For sound blending, children listened to separately articulated sounds and were asked to put them together by saying aloud the word the sounds make when put together. In a third activity, letter-sound correspondences for four vowels and five consonants were taught. This was accomplished through the following activities: selecting and holding-up the letter 
matching the speech sound articulated by the teacher, saying the first sound of a drawing and putting the drawing inside a bag with the correct letter, or playing lettersound bingo games. The three activity types described above were included in each lesson. For example, one lesson started with the 'Say-It-and- Move-It' activity in which participants first repeated the target word and then moved markers along a grid as they pronounced the separate phonemes in the word. After segmenting the word, they blended the sounds again and pronounced the word as a unit. In a different activity, a puppet told a rhyming story elongating the individual sounds in target words, so that each sound in the word could be heard distinctively. Then children were asked to blend the sounds into a word, as it would normally be pronounced. Finally, the teacher provided children a letter-sound knowledge activity. After introducing a few letters from previous lessons, the teacher put five lunch bags on a table with a letter printed on each of them. Then, the teacher distributed one picture to every child in the class. Each child said aloud the first sound of the picture and placed the card inside the bag with the corresponding letter.

Adaptations to the Blachman et al. (2000) program consisted of adding an initial sound isolation activity and changing the order of the alphabetic sounds introduced throughout the lessons. In Spanish, prolongable sounds (vowels, fricatives, nasals and liquids) are easier to isolate than interrupted sounds (occlusives and affricates), thus, the alphabetic sounds selected were introduced in the following order: 1) vowels $/ \mathrm{A} /$, /E/, /O/; 2) prolongable consonants /M/ and /S/; and 3) interrupted sounds /P/ and $/ \mathrm{T} /$. The sounds $/ \mathrm{L} /$ and $/ \mathrm{N} /$ were introduced at the end of the program to increase the number of words children could create during the sound board activities.

To control for the Hawthorne effect, the control group received a shorter program focused on grammar development (e.g., making sentences, breaking sentences into words). It included six sessions of 30 minutes each. The control and the experimental groups used the same materials to complete different activities as follows: (a) The control groups connected pictures to create short sentences, while the experimental groups categorized the same pictures by shared sounds; (b) The control groups manipulated rubber disks to segment sentences in words, the experimental groups used the same disks to segment words into sounds.

To check for fidelity of implementation, four trained research assistant observed ten randomly selected lessons and completed a checklist detailing 1) expected length of the lesson, 2) activities delivered according to the script, 3) availability of the materials detailed in the script, 4) expected use of the materials, 5) students engagement, 6) expected modelling of activities, and 7) ability to deliver the lesson. A score from 1 to 4 was given to each variable as follows: $1=$ Deficient, $2=$ Basic, $3=$ Good, $4=$ Very good. The seven dimensions show minimal variability across the different lessons observed. Dimensions 1 to 6 show no variability; the teachers achieved the highest category 'very good' across all lessons. Dimension 7 showed 
some variability. Accordingly, the percentage of fidelity treatment for dimensions 1 to 6 was $100 \%$ with all in the 'very good' category and for dimension 7 was $80 \%$ in the 'very good' category and $20 \%$ in the 'good' category.

\subsection{Measures}

\subsubsection{Demographic measures}

Data on level of parental education, SES and family literacy, were collected to ensure that children from the experimental group did not significantly differ from children in the comparison group in key variables that are known to contribute to literacy.

Level of parental education. Using school records, the level of parental education was calculated averaging years of school attendance by both parents as follows. The average values were classified into the three following categories: low (average value lower than high-school: 1-11 years); middle (average value equivalent to high school diploma, some intermediate or post-high school non-college education, and some years in college) 12-15 years); and high (average value equivalent to college and above: 16 years and above).

Socioeconomic status. We created a combined measure of the head-of-family occupation and education (Comisión de Enlace Institucional- Institutional Liaison Commission, 2006). We obtained the head of the family's occupation and education from the school records using three categories: (1) low (Occupation: employee, parttime skilled worker or self-employed partial occupation or below; Education: number of school years lower than high school); (2) middle (Occupation: employee; semiprofessional or full-time self-employed or part-time independent professional. Education: number of school years equivalent to high school; some intermediate or post-high school non-college education and at least three years in college; and (3) high (Occupation: dependent professional and full-time independent professional or partner or business owner. Education: completed college, graduate school, or above).

Home literacy environment. Each child's primary caregiver completed a questionnaire adapted from the Interview for Primary Caregiver (Dickinson \& Tabors, 2001). We created a composite literacy environment score using the following items: frequency of shared book reading, frequency of child's private play with books, number and types of books in the home, places to obtain books, presence and name of a favorite book, and frequency of caregiver's private reading. Values from five to 8.5 were coded as low, from 8.5 to 12 as medium and from 12 to 15.5 as high. 


\subsubsection{Screening measure}

The tasks were administered in Spanish to every child over three, 20-minute sessions on three different days, and the task order was randomized across children within each assessment session. The screening took place in a quiet room at the school. It was administered by the researcher as well as graduate students from the Speech-Language Pathology program who received a four-hour training.

\subsubsection{General cognitive ability}

This measure was used to identify children who did not meet inclusion criteria. We administered two subtests of the Wechsler Preschool and Primary Scale of Intelligence (WIPPSI): the vocabulary and block design subtests (Sattler, 1992). Data from children who scored below the $70^{\text {th }}$ percentile were excluded from analyses.

\subsubsection{Literacy measures}

Word reading. We assessed reading using the Basic Reading Skills Cluster from the Woodcock-Johnson Tests of Achievement (Woodcock \& Muñoz-Sandoval, 1996) which combines the Letter-Word Identification and the Word Attack subtests. It required children to read high-frequency words and nonwords. Both subtests have a median internal consistency reliability of 0.9 in ages 5 to 9 .

Spelling. This task, by Signorini and Borzone (2003), consists of writing six lists of words: 1) high frequency short and long words with consonant-vowel syllables (eight items); 2) high frequency short and long words with complex phonological structure, e.g., consonant-vowel-consonant (eight items); 3) low frequency short and long words (eight items); 4) low frequency short and long complex words (eight items); 5) orthographic complex words (eight items) and 6) pseudowords (ten items). A phonological criterion was used to score this task: one point was assigned to each word in which all the phonemes were represented. The task has an internal consistency reliability of 0.99 on the word lists and of 0.92 on the pseudoword list.

Reading comprehension. In this test by Woodcock and Muñoz-Sandoval (1996), the first four items were presented in a multiple-choice format. The children pointed to the drawing that best represented the sentence they read. Subsequent items assessed the child's ability to decode an incomplete sentence and find the word that best completes the sentence. It contained 43 items and each correct answer received one point. The test was interrupted after six consecutive incorrect answers. It has an internal consistency reliability of 0.9 for age six.

Letter-name and sound knowledge. Twenty-five uppercase letters were presented individually in random order on individual cards. Children were asked to say the name, the sound, and a word that starts with the letter sound. One point was 
scored for each correct answer. The three activities were scored separately. The median internal consistency reliability of this task is 0.90 .

\subsubsection{Phonological awareness measures}

Sound blending (Woodcock \& Muñoz-Sandoval, 1996). The child listens to a series of syllables or phonemes and blends the sounds into a word. This task has a median internal consistency reliability of 0.86 in ages five to 19 .

Initial sound identification task (Signorini \& Borzone, 2003). Ten items, consisting of three drawings each were presented on a chart (one in the upper part and two in the lower part of the chart). The Initial Phoneme Identification tasks required children to identify which of two drawings located in the lower part of the chart start with the same sound as the drawing located in the upper part of the chart. The median internal consistency reliability of the task is equal to 0.75 .

Final syllable identification task. This task, by Signorini and Borzone (2003) is composed of 10 items. Each item consists of three drawings presented on a chart (one in the upper part and two in the lower part of the chart). Children were asked to identify which of the drawings located in the lower part of the chart end with the same syllable as the drawing in the upper part of the chart. The median internal consistency reliability of the task is equal to 0.80 .

Phoneme segmentation (Manrique \& Gramigna, 1985). Children were asked to break words into their individual sounds by positioning a marker for each sound. For example, "How many sounds in 'más' (3: / m/ /a/ / s/)". The task is composed of 42 words presented randomly from each of three conditions: 14 single phoneme words, 14 two-phoneme words, and 14 three-phoneme words. The maximum score was 42 . The median internal consistency reliability is equal to 0.84 .

Syllable and phoneme isolation task (Jiménez \& Ortiz, 1995). Children selected from a series of five drawings, the one that starts with the syllable or sound given by the experimenter. It has an internal consistency reliability of 0.62 and has eight items.

Syllable and phoneme deletion task (Jiménez \& Ortiz, 1995). The child was asked to omit a target sound or syllable saying aloud the rest of the word. It has an internal consistency reliability of 0.91 .

\subsection{Analyses}

We run independent sample $t$-tests to compare the intervention and comparison group in terms of demographic variables, general cognitive ability, and reading level at pre-test. To examine the effect of the intervention on PA and reading measures, we ran 11 separate general linear ANOVAS models with repeated measures to assess the effect of the intervention program on the linguistic and literacy variables assessed. For 
all cases, a three-factor partially nested design was applied. The model factors were time $(A=3)$, condition $(B=2)$, and subjects $(D=178)$. Subject was nested with condition, as well as entered as a random variable. An alpha level of 0.05 was used to test the significance of all statistical tests.

\section{Results}

\subsection{Effects on Phonological Awareness}

Below we present the effects of the intervention on each aspect of PA measured (Table 2).

Table 2. Least Square Means, Standard Errors (in Parentheses), $t$ and $p$ values for the Control and the Experimental Group at Pretests, Posttests 1 and Posttest 2 for literacy and linguistic variables as well as effect size values.

\begin{tabular}{|c|c|c|c|c|c|c|c|c|c|c|c|c|c|c|c|}
\hline \multirow[b]{2}{*}{ Measure } & \multicolumn{5}{|c|}{ Pretest - Beginning of K. } & \multicolumn{5}{|c|}{ Posttest 1 - End of K. } & \multicolumn{5}{|c|}{ Posttest 2 - End of Grade 1} \\
\hline & $\begin{array}{c}\mathrm{C} \\
(\mathrm{n}=71) \\
\end{array}$ & $\begin{array}{c}\mathrm{E} \\
(\mathrm{n}=101)\end{array}$ & $t$ & $p$ & $d$ & \begin{tabular}{|c|}
$\mathrm{C}$ \\
$(\mathrm{n}=68)$ \\
\end{tabular} & \begin{tabular}{|c|}
$\mathrm{E}$ \\
$(\mathrm{n}=83)$ \\
\end{tabular} & $t$ & $p$ & $D$ & \begin{tabular}{|c|}
$\mathrm{C}$ \\
$(\mathrm{n}=57)$ \\
\end{tabular} & $\begin{array}{c}\mathrm{E} \\
(\mathrm{n}=70)\end{array}$ & $t$ & $p$ & $d$ \\
\hline Word Reading & $\begin{array}{c}383.76 \\
(2.4)\end{array}$ & $\begin{array}{c}382.87 \\
(2.2) \\
\end{array}$ & 0.26 & 0.79 & 0.04 & $\begin{array}{c}385.67 \\
(2.4)\end{array}$ & $\begin{array}{c}388.82 \\
(2.3)\end{array}$ & 0.85 & 0.39 & 0.14 & $\begin{array}{c}436.40 \\
(2.9) \\
\end{array}$ & $\begin{array}{c}450.78 \\
(2.5)\end{array}$ & 3.78 & 0.000 & 0.70 \\
\hline Spelling & $\begin{array}{l}0.41 \\
(0.8)\end{array}$ & $\begin{array}{l}0.23 \\
(0.8)\end{array}$ & 0.14 & 0.88 & 0.02 & $\begin{array}{l}0.53 \\
(0.9)\end{array}$ & $\begin{array}{l}1.16 \\
(0.8)\end{array}$ & 0.36 & 0.71 & 0.08 & \begin{tabular}{|c|}
23.29 \\
$(0.9)$ \\
\end{tabular} & $\begin{array}{c}28.51 \\
(0.9)\end{array}$ & 3.72 & 0.000 & 0.70 \\
\hline Reading Comprehension & & & & & & & & & & & $\begin{array}{c}424.15 \\
(5.6)\end{array}$ & $\begin{array}{c}440.11 \\
(4.8)\end{array}$ & 2.14 & 0.034 & 0.40 \\
\hline Letter Name-Sound Knowledge & $\begin{array}{l}3.40 \\
(0.7) \\
\end{array}$ & $\begin{array}{l}3.88 \\
(0.6)\end{array}$ & 0.49 & 0.62 & 0.09 & $\begin{array}{l}8.04 \\
(0.9)\end{array}$ & $\begin{array}{c}11.49 \\
(0.8)\end{array}$ & 2.73 & 0.007 & 0.67 & & & & & \\
\hline Initial Sound Identity & $\begin{array}{l}6.42 \\
(0.2)\end{array}$ & $\begin{array}{l}6.11 \\
(0.2)\end{array}$ & 1.53 & 0.12 & 0.19 & $\begin{array}{l}7.14 \\
(0.2)\end{array}$ & $\begin{array}{l}8.08 \\
(0.2)\end{array}$ & 3.48 & 0.000 & 0.59 & $\begin{array}{l}8.43 \\
(0.2)\end{array}$ & $\begin{array}{l}8.91 \\
(0.2)\end{array}$ & 1.56 & 0.119 & 0.30 \\
\hline Rhyme Identity & $\begin{array}{l}7.18 \\
(0.2)\end{array}$ & $\begin{array}{l}7.06 \\
(0.2) \\
\end{array}$ & 0.40 & 0.34 & 0.07 & $\begin{array}{l}7.73 \\
(0.2)\end{array}$ & $\begin{array}{l}8.67 \\
(0.2)\end{array}$ & 2.96 & 0.003 & 0.54 & $\begin{array}{l}9.01 \\
(0.2)\end{array}$ & $\begin{array}{l}8.93 \\
(0.2)\end{array}$ & 1.00 & 0.318 & 0.04 \\
\hline Phoneme Segmentation & $\begin{array}{l}0.72 \\
(1.2) \\
\end{array}$ & $\begin{array}{l}0.91 \\
(1.1) \\
\end{array}$ & 0.11 & 0.91 & 0.01 & $\begin{array}{l}5.51 \\
(1.2) \\
\end{array}$ & \begin{tabular}{|c|}
13.68 \\
$(1.1)$ \\
\end{tabular} & 4.81 & 0.000 & 0.81 & $\begin{array}{l}28.7 \\
(1.3) \\
\end{array}$ & $\begin{array}{l}28.5 \\
(1.2) \\
\end{array}$ & 0.10 & 0.92 & 0.20 \\
\hline Sound Blending & $\begin{array}{c}452.47 \\
(1.4) \\
\end{array}$ & $\begin{array}{c}451.51 \\
(1.4) \\
\end{array}$ & 0.52 & 0.60 & 0.08 & $\begin{array}{c}453.24 \\
(1.4)\end{array}$ & $\begin{array}{c}459.26 \\
(1.4) \\
\end{array}$ & 2.94 & 0.003 & 0.55 & \begin{tabular}{|c|}
459.48 \\
$(1.4)$ \\
\end{tabular} & $\begin{array}{c}465.99 \\
(1.4)\end{array}$ & 3.11 & 0.002 & 0.59 \\
\hline Syllable and phoneme isolation task & $\begin{array}{l}2.83 \\
(0.2) \\
\end{array}$ & $\begin{array}{l}2.65 \\
(0.2) \\
\end{array}$ & 0.62 & 0.53 & 0.10 & $\begin{array}{l}2.69 \\
(0.2) \\
\end{array}$ & $\begin{array}{c}2.69 \\
(0.21)\end{array}$ & 0.003 & 0.99 & 0.00 & $\begin{array}{l}4.41 \\
(0.2) \\
\end{array}$ & $\begin{array}{l}4.11 \\
(0.2) \\
\end{array}$ & 0.98 & 0.32 & 0.34 \\
\hline Syllable and phoneme deletion task & $\begin{array}{l}2.64 \\
(0.4) \\
\end{array}$ & $\begin{array}{l}2.25 \\
(0.4) \\
\end{array}$ & 0.29 & 0.77 & 0.18 & $\begin{array}{l}2.35 \\
(0.4) \\
\end{array}$ & $\begin{array}{c}2.87 \\
(0.41) \\
\end{array}$ & 0.84 & 0.40 & 0.16 & $\begin{array}{l}8.64 \\
(0.4) \\
\end{array}$ & $\begin{array}{l}.58 \\
(0.4) \\
\end{array}$ & 1.43 & 0.15 & 0.28 \\
\hline
\end{tabular}

Effects of the intervention on initial sound identification. There was a significant time x condition interaction, $F(2,270)=6.3, p=0.002$. Follow-up analyses of the interaction revealed that at posttest 1 children who received the phonological awareness intervention scored higher than children in the control group, $t(270)=3.4$, $p<0.000$ (two-tailed). Root Mean Square Standardized Effects RMSSE (calculated as the mean difference between children in the two groups by the pooled within-cell error term of the model-root mean square error) for the posttest 1 difference was 0.59. The difference was no longer significant at posttest 2 (see Table 2 and Figure 1a).

Effects on rhyme identification. There was a significant time $\mathrm{x}$ condition interaction, $F(2,264)=8.1, p=0.0004$. Interaction analyses revealed that at posttest 1 children in the experimental condition showed greater rhyme identification scores $(M$ $=8,67, S E=0.2)$ than children in the control group $(M=7.73, S E=0.2), t(264)=$ 
2.9, $p=0.003$ (two-tailed). The RMSSE effect size was 0.5. At posttest 2, the experimental group did not differ from the control group (see Table 2 and Figure 1b).

Effects on phoneme segmentation. There was a significant effect for time $F(2$, $264)=277, p<0.0001$, intervention $F(2,175)=6.4, p=0.01$ and a significant time $x$ condition interaction $F(2,264)=6.3, p<0.0001$. The experimental group showed greater scores $(M=14.38, S E=0.7)$ than the control group $(M=11,66, S E=0.7), t$ $(178)=2.7, p=0.007$ (two-tailed). At posttest 1 , children who received the intervention on PA showed greater scores on phoneme segmentation than children in the control group, $t(264)=4.8, p=<0.000$ (two-tailed). The RMSSE effect size for this difference was 0.8 (see Table 2 and Figure 1c). There were no differences between the two groups at posttest 2 (end of grade one).

Effects on sound blending. There was a significant effect for time $F(2,249)=$ $277, p<0.0001$, intervention $F(2,173)=9.06, p=0.003$, and a significant time $\mathrm{x}$ condition interaction $F(2,249)=5.4, p=0.004$. At posttest 1 , children in the experimental group showed greater scores on sound blending than children in the control group, $t(249)=2.9, p=0.003$ (two-tailed). The RMSSE effect size for the posttest 1 difference was 0.55 . This difference was also significant at posttest 2 (end of first grade), $t(249)=3.1, p=0.002$ (two-tailed). The RMSSE effect for the posttest 2 difference was 0.59 (see Table 2 and Figure 1d).

Effects on syllable and phoneme isolation. There was a significant effect for time, $F(2,271)=33.7, p=<0.0001$. There was no significant main effect for intervention or a significant time x condition interaction.

Effects on syllable and phoneme deletion. There was a significant effect for time, $F(2,271)=33.7, p=<0.0001$. There was no significant main effect for intervention or a significant time $\mathrm{x}$ intervention interaction.

\subsection{Effects on literacy skills}

Effects on letter-name sound knowledge. There was a significant effect for time $F(1,76)=71.5, p<0.0001$, intervention $F(1,180)=5.2, p=0.02$, and a significant time $x$ condition interaction $F(1,76)=4.2, p=0.04$. Analysis of the interaction revealed that, at posttest 1 , children that received the intervention in $\mathrm{PA}$ scored significantly higher than children in the control group, $t(76)=2.8, p=0.006$ (two-tailed). The RMSSE effect size for the posttest difference was 0.67 (see Table 2 and Figure 2a).

Effects on word reading. There was a significant effect for time $F(2,268)=364$, $p<0.0001$, intervention $F(1,175)=5.8, p=0.01$, and a significant time $\mathrm{x}$ condition interaction $F(2,268)=4.2, p=0.006$. Follow-up analyses of the interaction revealed that although the two groups were not significantly different at posttest 1 , at posttest 2 
children who received the intervention in PA scored greater in word reading $(M=$ $450,78, S E=2.5)$ than children who did not received this intervention $(M=436.40$, $S E=2.9), t(268)=3.7, p<0.0001$ (two-tailed). The RMSSE effect size for this interaction effect was 0.70 (see Table 2 and Figure $2 \mathrm{~b}$ ).

Effects on spelling. There was a significant effect for time $(F(2,254)=488.3, p$ $<0.0001)$, condition $(F(1,174)=6.0, p=0.00)$, and a significant time $\mathrm{x}$ condition interaction $(F(2,254)=4.8, p=0.008)$. The analyses of the interaction revealed that although the two groups were equivalent at posttest one, at posttest two children in the experimental group scored higher $(M=28.5, S E=0.9)$ on spelling than children in the control group $(M=23.2 \mathrm{SE}=0.9), t(254)=3.7, p=0.002$ (two-tailed). RMSSE effect size for the posttest 2 difference was 0.70 (see Table 2 and Figure 2c).

Effects on reading comprehension. There was a main effect of condition; children who received the PA intervention scored significantly higher $(M=440.1, S E$ $=5.0)$ at posttest two on reading comprehension than children in the control group $(M=424.1, S E=5.6), t(117)=2.1, p=0.03$ (two-tailed). The $\eta 2$ effect size was 0.4). (see Table 2 and Figure 2d).

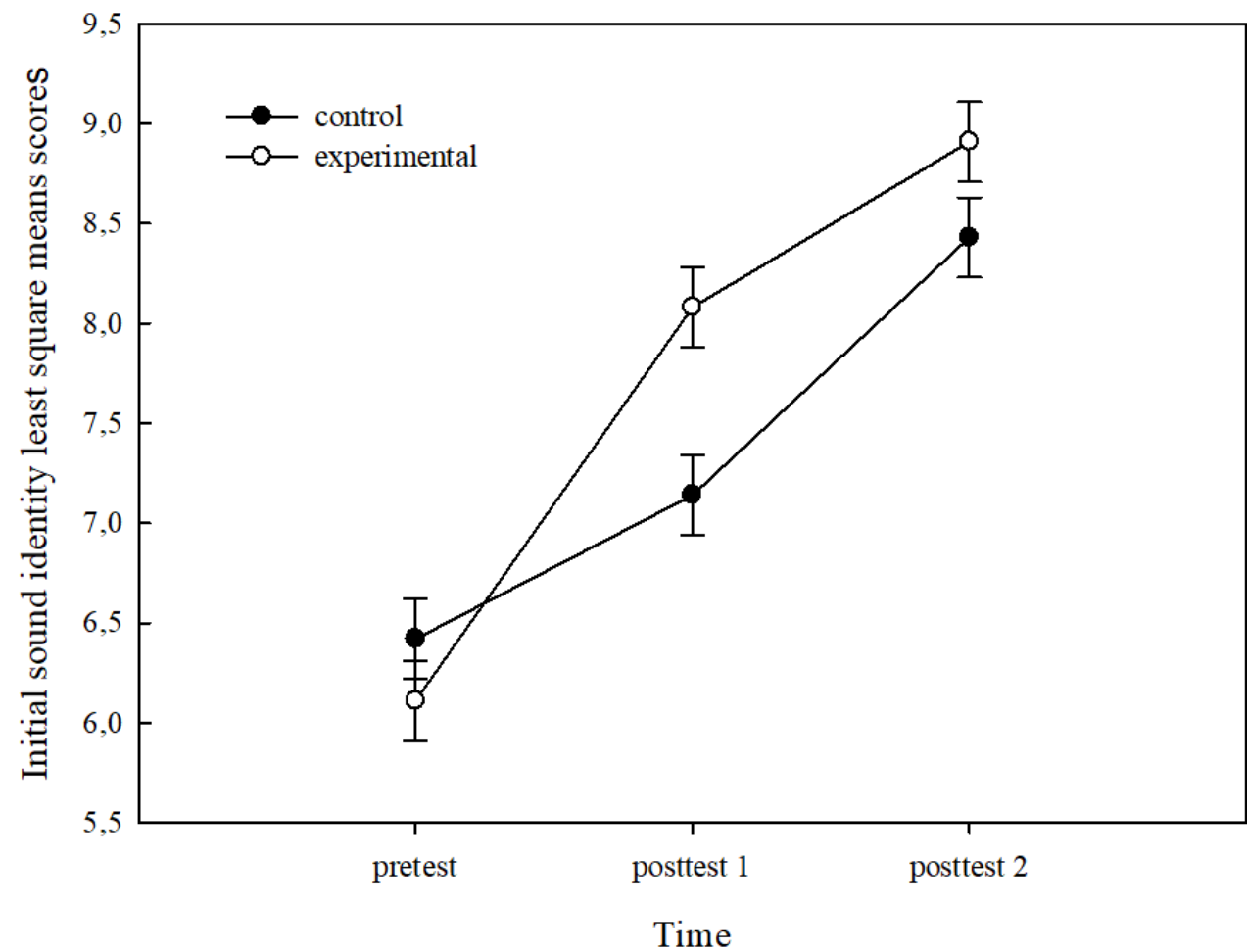

Figure 1a. Effects of time and condition on Initial Sound Identity 


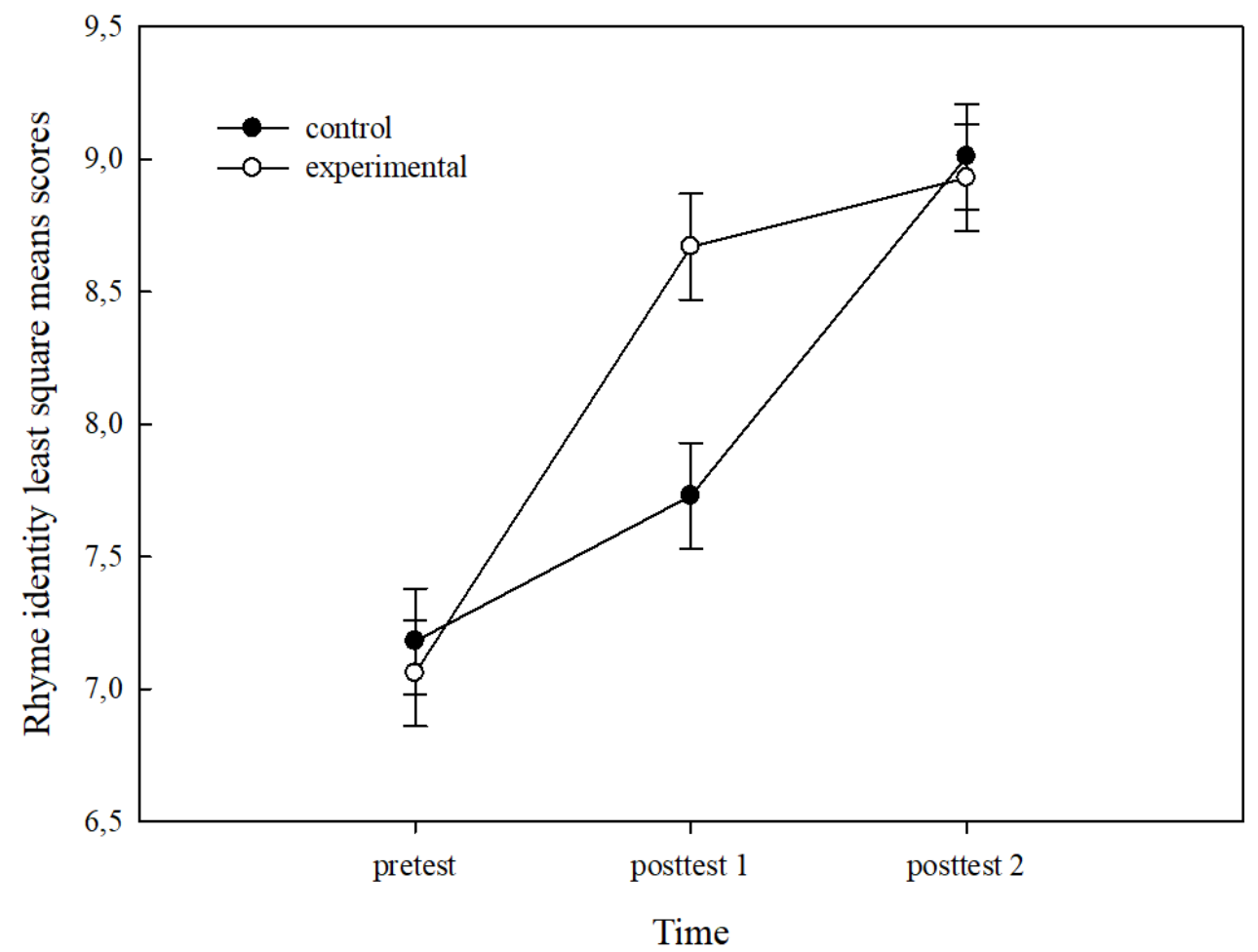

Figure 1b. Effects of tiem and condition on Rhyme Identity.

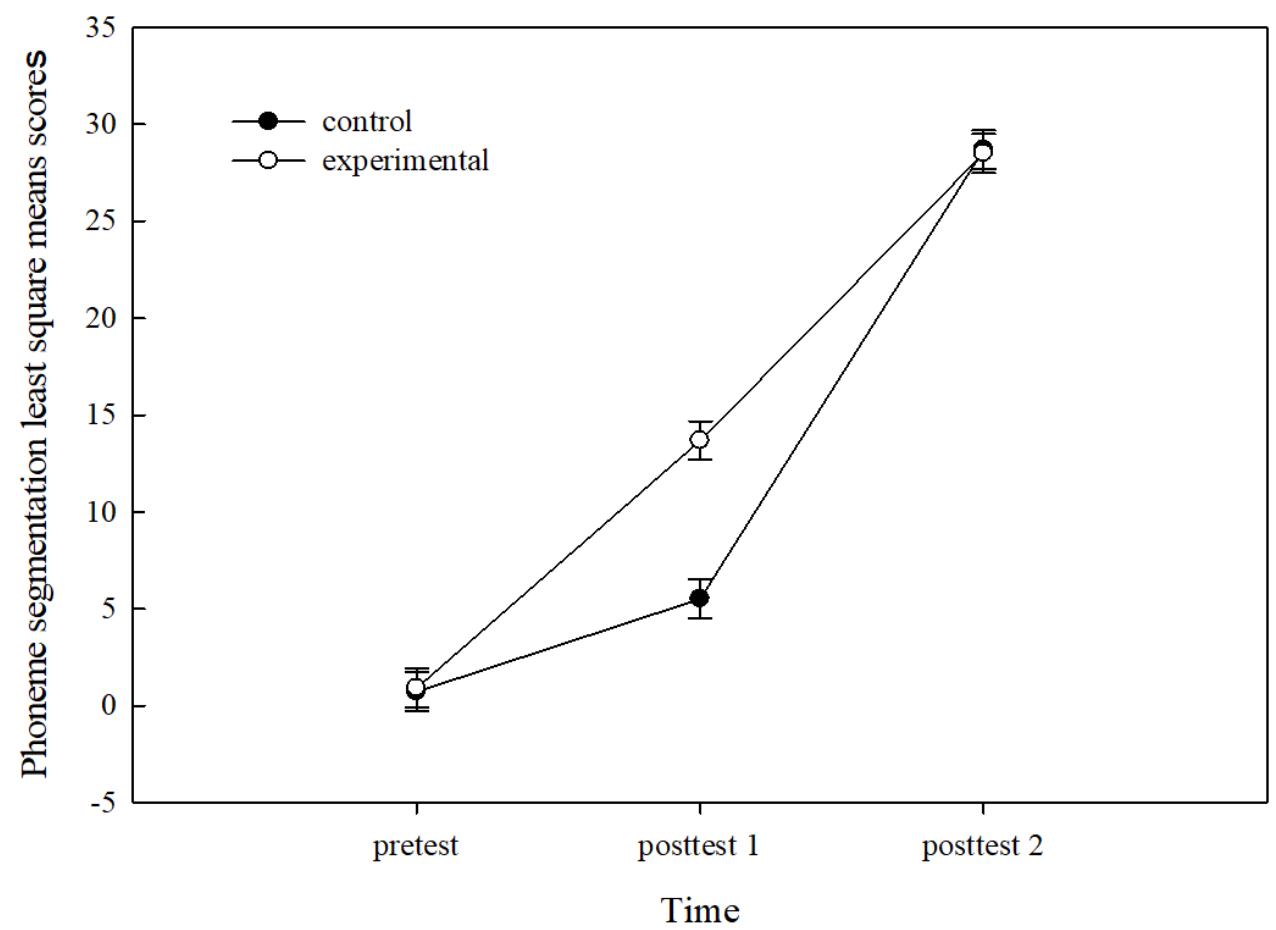

Figure 1c. Effects of time and condition on Phoneme Segmentation 


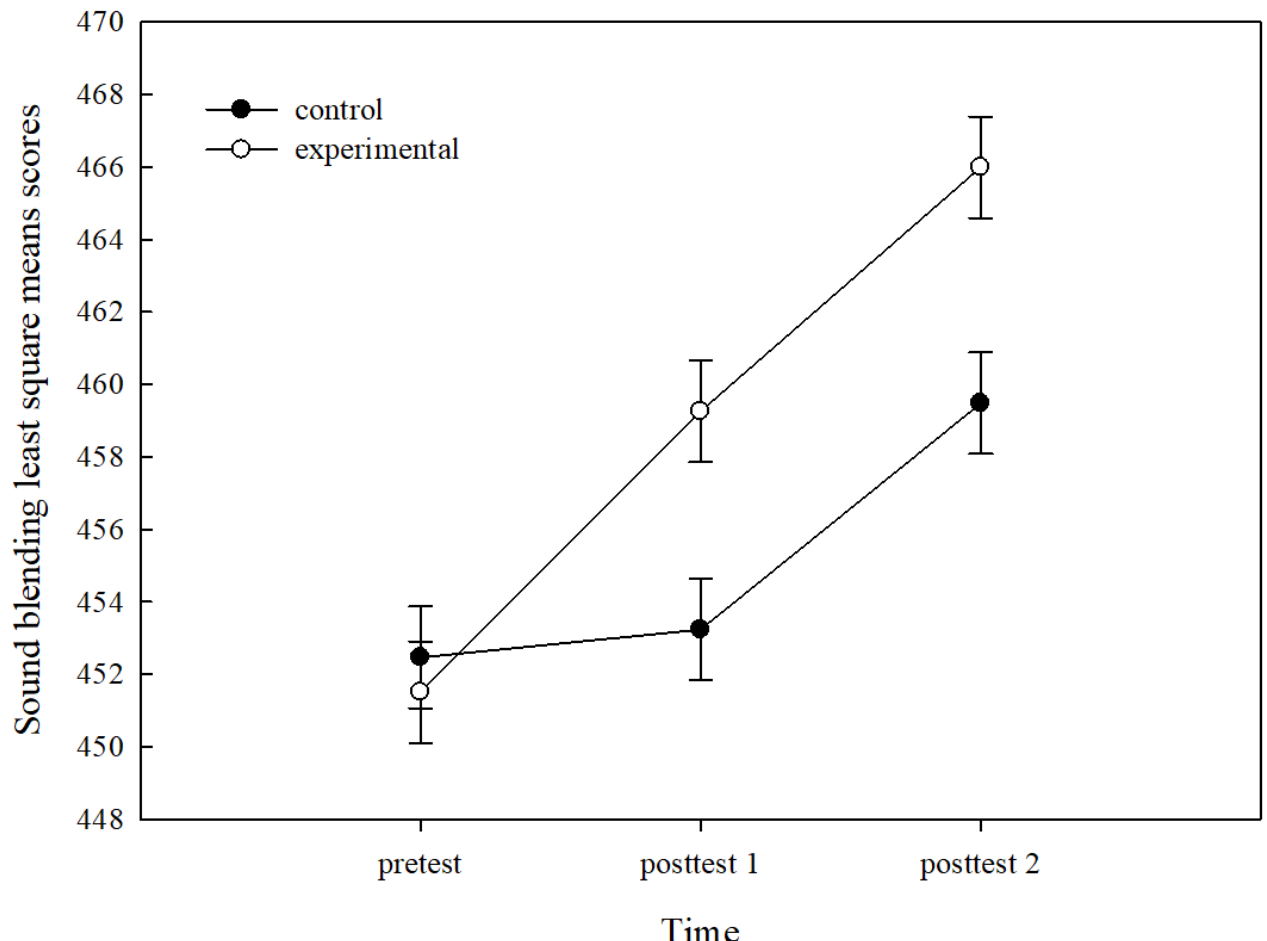

Figure 1d. Effects of time and condition on Sound Blending

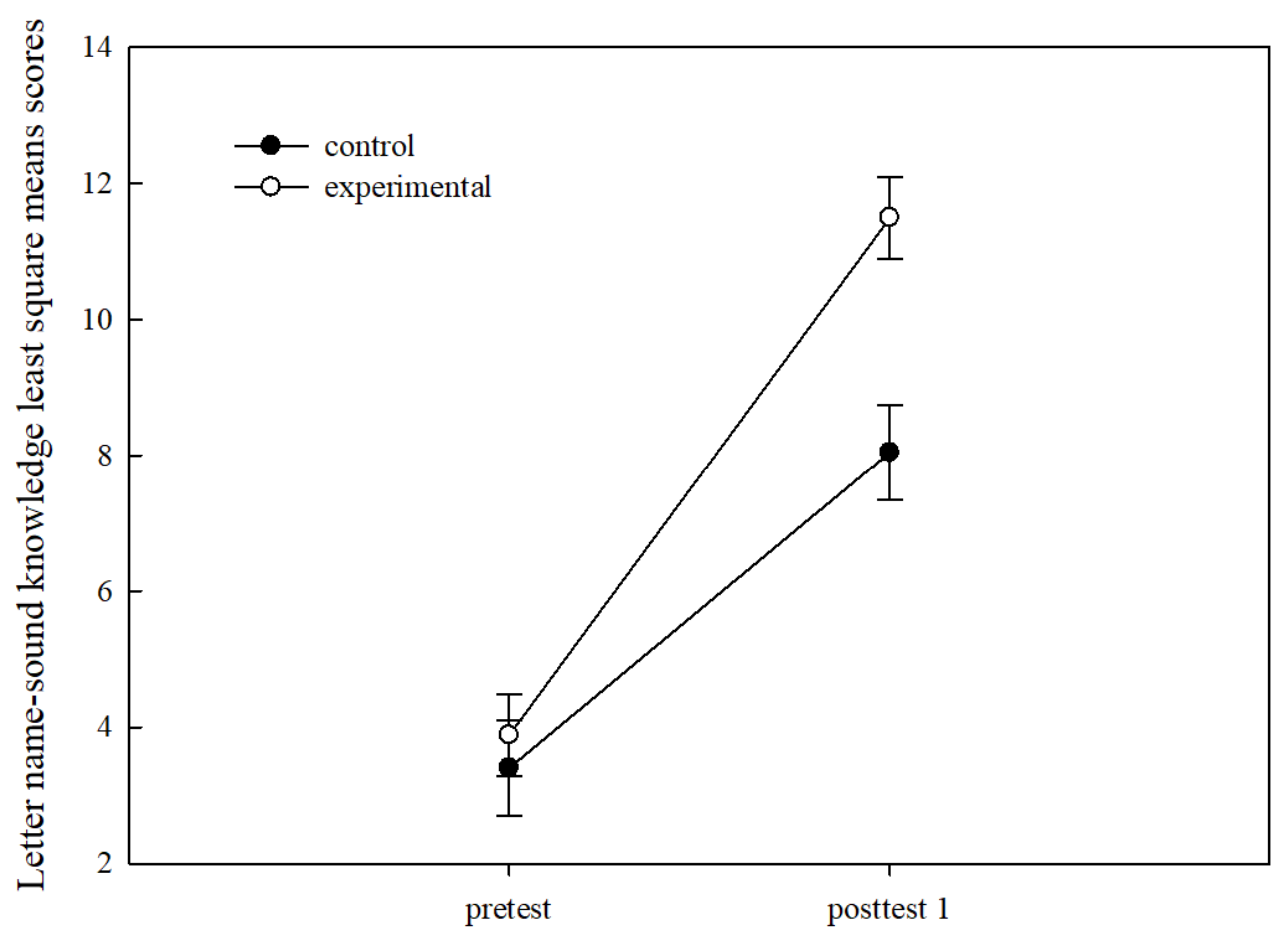

Time

Figure 2a. Effects of time and condition on Letter Name-Sound Knowledge. 


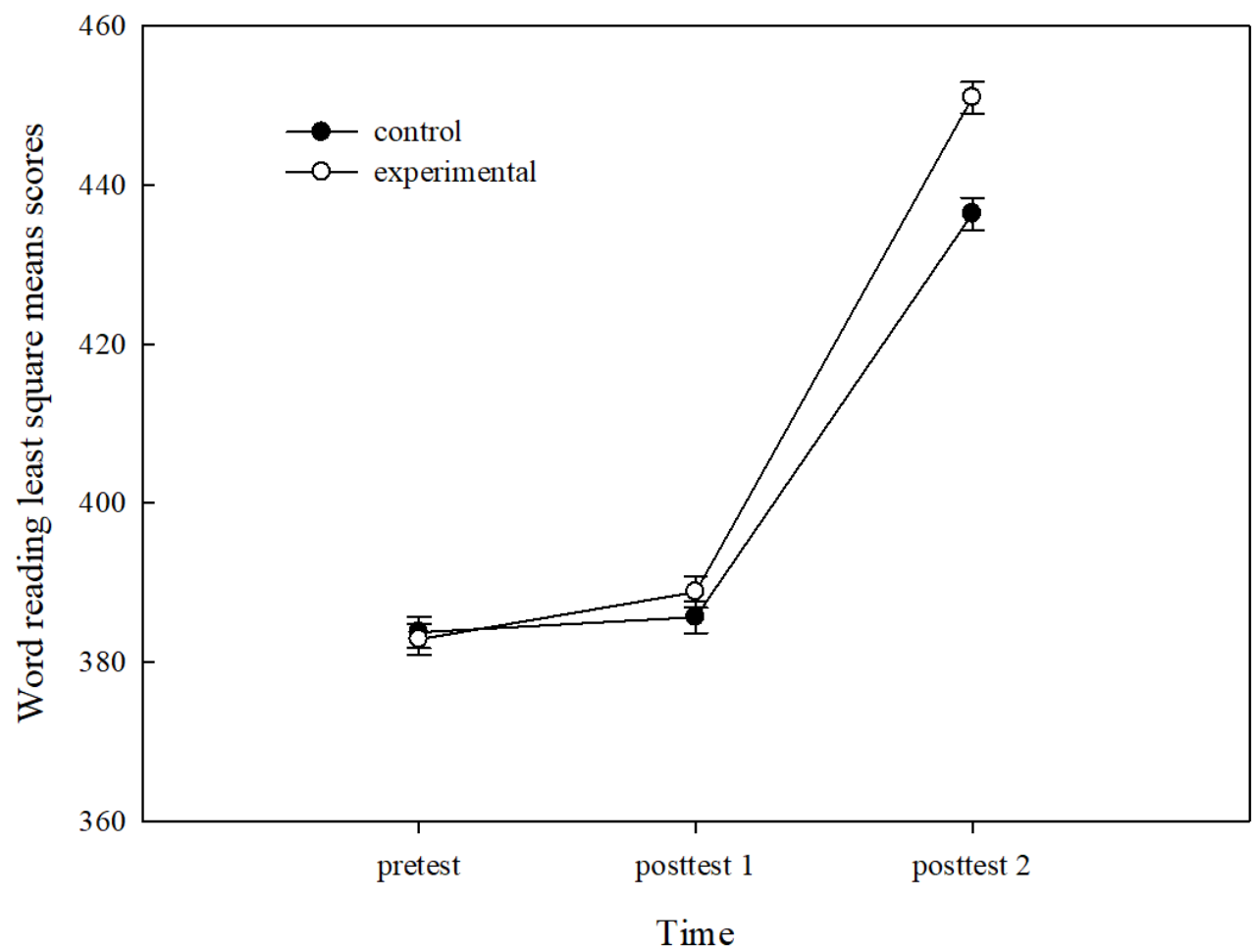

Figure 2b. Effects of time and condition on Word Reading.

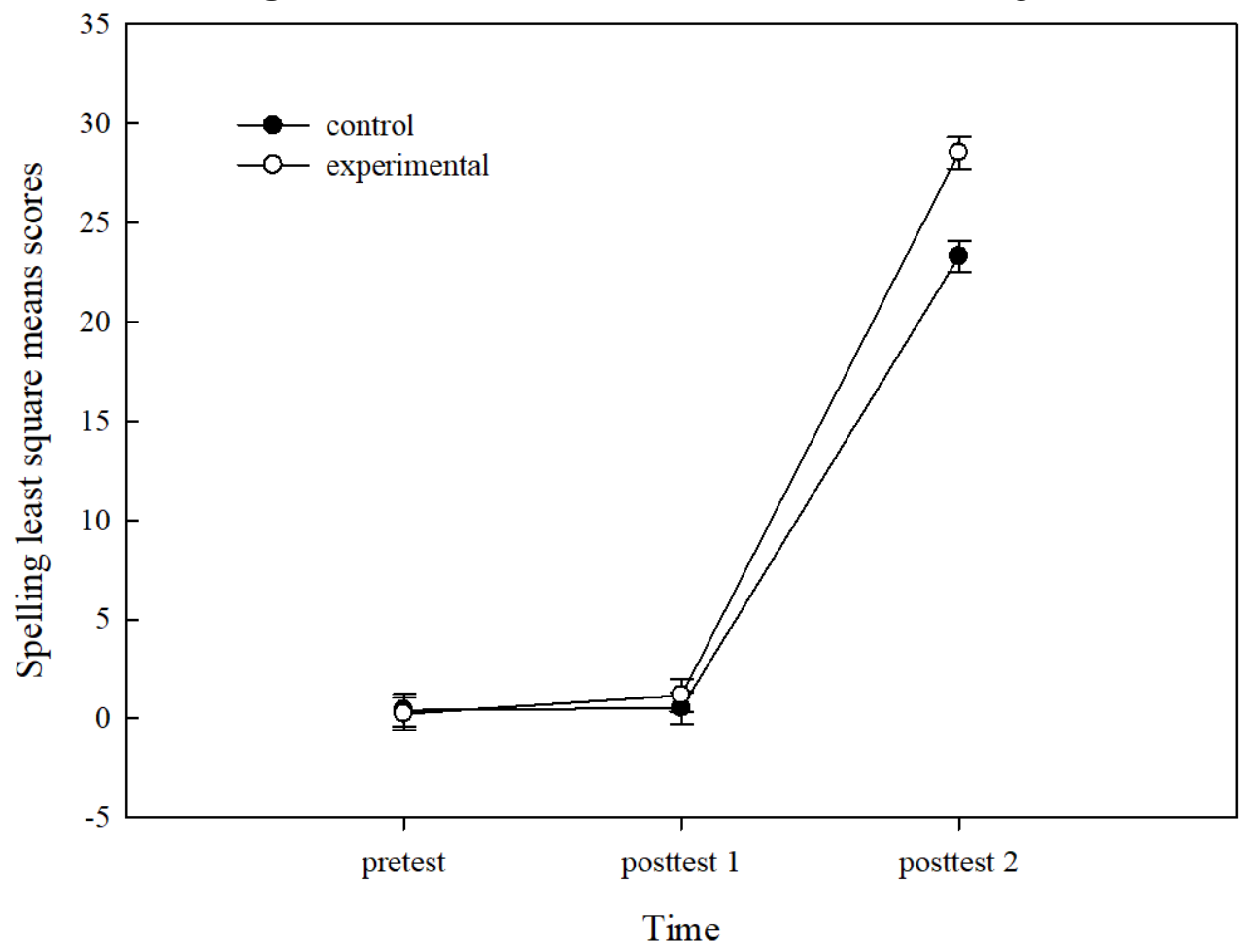

Figure 2c. Effects of time and condition on Spelling. 


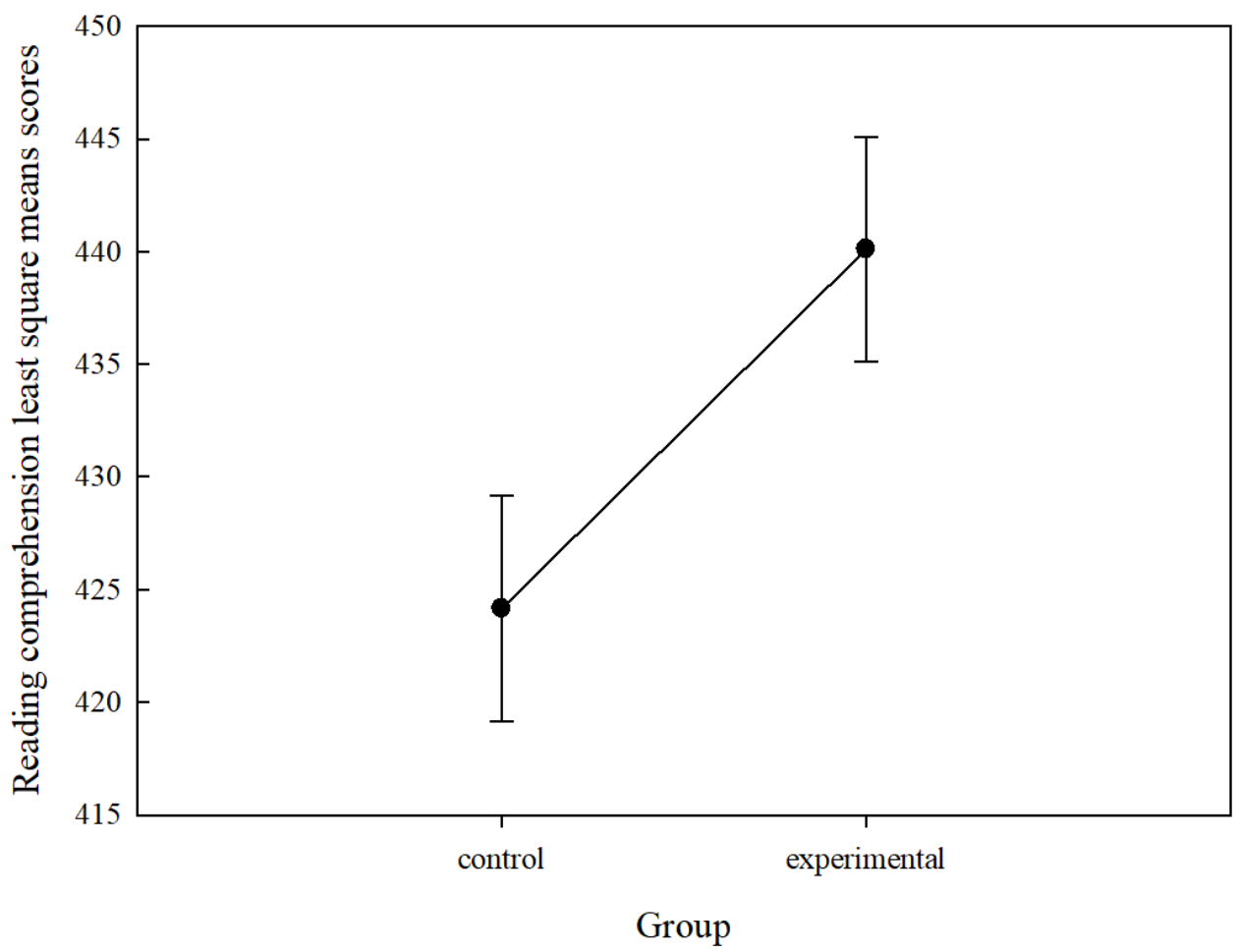

Figure 2d. Effects of time and condition on Reading Comprehension.

\section{Discussion}

This study examined short- and long-term effects of a kindergarten PA intervention program for Spanish-speaking children on word reading, spelling, reading comprehension, letter-name sound knowledge and PA. It used a variety of PA measures and controlled for the Hawthorne effect by including an alternative intervention with similar materials to the control groups but with a different focus.

In relation to effects on PA, a significant short-term impact was observed on initial sound identification, rhyme identification, phoneme segmentation, and sound blending. A long-term effect was observed on initial sound identification and sound blending only. In relation to literacy measures, children who received the intervention performed significantly better than children in the comparison group on letter-name sound knowledge at post-test one. More importantly, significant long-term effects on word reading, spelling, and reading comprehension were found.

One of the most impressive and promising findings is that growth was observed not only on PA (the trained ability), but also on word reading, spelling, and reading comprehension more than one year after receiving the intervention. These findings present a significant contribution to knowledge of the effects of a kindergarten PA intervention in Spanish on literacy outcomes of grade one children, as most previous research conducted on Spanish-speaking kindergarteners (e.g., Herrera, et al., 2007; 
Arancibia, et al., 2012; Báez, Garzón, Macías, Pabón, Triana \& Espinosa, 2012; Bizama, et al., 2013) has either not examined long-term effects, or have not included reading comprehension. For example, Arancibia, et al. (2012) assessed short-term effects of a PA program on some aspects of PA but did not assess long-term effects nor did they examine effects on reading outcomes. Similarly, Baez et al. (2012) and Bizama et al. (2012) assessed the short-term impact of a PA intervention program delivered to kindergarteners on PA only. Herrera et al. (2007) examined long-term effects of two PA training programs on short-term verbal memory, naming speed performance, PA and letter knowledge. Consistent with the present study, the authors found significant long-term effects on letter knowledge. Their study, however, did not examine effects on word reading. Thus, this is perhaps the first study conducted in Latin America showing positive long-term effects of a kindergarten PA intervention on literacy outcomes at the end of kindergarten and grade one.

The significant growth in word reading, spelling, letter-name sound knowledge, and reading comprehension by the group receiving the PA intervention might be explained by the inclusion of the letter-name sound knowledge of eight letters of the alphabet along with explicit instruction on PA. The PA intervention helped children to detect sounds in words enabling them to decode words more easily. This finding is consistent with Ehri et al.'s (2001) conclusion that interventions are more likely to be effective when letters are taught because this supports the phonological processing of print, the learning of the letter-sound correspondences and the development of phonemic awareness (Foulin, 2004). It also aligns with results from GutiérrezFresneda, et al., 2020) who found that children who had begun their reading training had stronger PA than those who had not. Although researchers (e.g., Bravo Valdivieso et al., 2006) advocate for the teaching of PA to accelerate reading acquisition, this is the first study directly showing the effectiveness of PA in increasing reading and spelling among low socioeconomic status kindergarten children who are monolingual Spanish speakers.

In accordance with previous studies, we found short-term effects of our intervention on all the PA abilities assessed. However, significant long-term effects were observed only on initial sound identification and sound blending. A possible explanation for the absence of long-term effects on rhyme identification is that awareness of syllables, which is inherent to the rhyming task, is achieved around age four (Anthony et al., 2011; Gutiérrez-Fresneda et al., 2020). In our sample, there was a ceiling effect by grade one, with most children (75\% of the children) obtaining a score above the superior quartile. Thus, it seems that this ability is well established at age six, the age of most children at the end of first grade. By contrast, the acquisition of phoneme awareness begins around age six when children start connecting sounds with their corresponding letters, and continues through the primary grades. This would explain why we found in grade one a difference between the control and the 
experimental group in the sound blending task. The long-term effects seen on more complex skills such as spelling, word reading, and reading comprehension suggest that the PA skills harnessed in kindergarten come to fruition during reading instruction in grade one. As children gained experience and facility mapping sounds to symbols, they may have developed efficient word reading which in turn facilitates their reading comprehension. Interestingly, impact on spelling and word reading was only observed at the end of grade one. As these tasks require more sophisticated knowledge of the alphabetic principle, it makes sense that it takes longer for the children to capitalize on the benefits of the PA training. This is consistent with Gutiérrez-Fresneda et al., 2019, who found that children already receiving reading instruction had stronger PA skills than those not yet introduced to it.

This study has some limitations. For example, given that some letter-sound knowledge training was provided, we cannot be certain that a purely PA training would result in the same gains and significant differences across groups. Moreover, it remains to be examined whether the kindergarten PA training effects would hold beyond grade one. In a study by Defior (2008), the effects of PA training in grade one disappeared by the end of grade two. It remains to be seen whether effects would fade out or remain after grade one when a comprehensive intervention is provided in kindergarten.

\section{CONCLUSION}

In the field of education, a convincing body of evidence usually translates into policy initiatives. However, for Spanish-speaking populations little evidence is available regarding the effects of kindergarten PA intervention programs on reading development. Therefore, this study strengthens the corpus of evidence that supports the benefits of PA training on reading acquisition for these children. The most significant contribution of the present study is that it provides further evidence that kindergarten literacy instruction that includes explicit PA training, including soundletter connection activities, facilitates the development of word reading, spelling and reading comprehension in grade one. It demonstrates that it is possible to intervene before children have acquired reading and writing skills and that the intervention facilitates their literacy development.

\section{REFERENCES}

Al Otaiba, S., Kosanovich, M. L. \& Torgesen, J. K. (2012). Assessment and instruction for phonemic awareness and word recognition skills. In A. G. Kamhi \& H. W. Catts (Editors), Language and reading disabilities (pp. 112-140). New York: Pearson. 
Anthony, J., Williams, J. M., Durán, L. K. \& Laing, S. (2011). Spanish phonological awareness: Dimensionality and sequence of development during the preschool and kindergarten years. Journal of Educational Psychology, 103(4), 857 876.

Arancibia, B., Bizama, M. \& Sáez, K. (2012). Application of stimulation program of phonological awareness in pre-school children and first year elementary school students, who attend socially vulnerable schools in Concepción, Chile. Revista Signos. Estudios de Lingüistica, 45(80), 236-256.

Báez, A. L., Garzón, M. A., Macías, J., Pabón, D., Triana, M. \& Espinosa, C. (2012). Intervención en conciencia fonológica (CF) en el aula para niños de primer ciclo. Cuadernos Hispanoamericanos, 12(2), 65-79.

Bizama, M., Arancibia, B. \& Sáez, K. (2013). Intervención psicopedagógica temprana en CV como proceso metalingüístico a la base de la lectura en niños de 5 a 6 años socialmente vulnerables. Estudios Psicopedagógicos, 39(2), 25-39.

Blachman, B., Ball, E., Black, R. \& Tangel, D. (2000). Road to the code. A phonological awareness program for young children. Baltimore, M.D.: Paul H. Brookes Publishing.

Borzone, A. M., Rosemberg, C., Diuk, B. \& Amado, B. (2005). Aprender a leer y escribir en contextos de pobreza. Lingüistica en el Aula, 9(8), 7-28.

Bowyer-Crane, C., Fricke, S., Schaefer, B., Lervag, A. \& Hulme, C. (2017). Early literacy and comprehension skills in children learning English as an additional language and monolingual children with language weaknesses. Reading and Writing, 30(4), 771-790. DOI: 10.1007/s11145-016-9699-8.

Branum-Martin, L., Tao, S. \& Garnaat, S. (2015). Bilingual phonological awareness: Reexamining the evidence for relations within and across languages. Journal of Educational Psychology, 107(1), 111-125.

Bravo Valdivieso, L., Villalón, M. \& Orellana, E. (2006). Predictibilidad del rendimiento en la lectura: Una investigación de seguimiento entre primer y tercer año. Revista Latinoamericana de Psicología, 38(1), 1-20.

Calet, N., Gutiérrez-Palma, N., Simpson, I. C., González-Trujillo, M. C. \& Defior, S. (2015). Suprasegmental phonology development and reading acquisition: A longitudinal study. Scientific Studies of Reading, 19(1), 51-71. DOI: 10.1080/10888438.2014.976342. 
Calet, N., Flores, M., Jiménez-Fernández, G. \& Defior, S. (2016). Habilidades fonológicas suprasegmentales y desarrollo lector en niños de Educación Primaria. Anales de Psicología, 32(1), 72-79. DOI: 10.6018/analesps.32.1.216221

Canales, Y. \& Porta, M. E. (2016). El nivel educativo y socioeconómico en el hogar y habilidades prelectoras en escuelas urbanas y urbano-marginales de la provincia de Mendoza. Actualidades Investigativas en Educación, 16(2), 1-26.

Canales, Y. \& Porta, M. E. (2018). Un estudio comparativo sobre el nivel de habilidades lingüísticas de niños de 4 y 5 años de escuelas urbanas y urbanomarginales. Psicopedagógica, 10(12), 86-108.

Caravolas, M., Lervåg, A., Mousikou, P., Efrim, C., Litavský, M., OnochieQuintanilla, E., Salas, N., Schöffelová, M., Defior, S., Mikulajová, M., Seidlová-Málková, G. \& Hulme, C. (2012). Common patterns of prediction of literacy development in different alphabetic orthographies. Psychological Science, 23(6), 678-686. DOI: 10.1177/0956797611434536.

Caravolas, M., Lervåg, A., Defior, S., Seidlová-Málková, G. \& Hulme, C. (2013). Different patterns, but equivalent predictors, of growth in reading in consistent and inconsistent orthographies. Psychological Science, 24(8) 13981407. DOI: $10.1177 / 0956797612473122$.

Carreiras, M. \& Perea, M. (2004). Naming pseudowords in Spanish: Effects of syllable frequency. Brain and Language, 90(1-3), 393-400.

Comisión de Enlace Institucional (2006). Nivel socioeconómico 2006 [on line]. Retrieved from: http://www.saimo.org.ar/archivos/observatoriosocial/NSE2006-23nov2006-Informe-final.pdf

Cuadro, A. \& Trías, D. (2008). Desarrollo de la conciencia fonémica: Evaluación de un programa de intervención. Revista Argentina de Neuropsicología, 11, 1-8.

Dauer, R. M. (1983). Stress-timing and syllable-timing reanalyzed. Journal of Phonology, 11, 51-6.

Davoudzadeh, P., McTernan, M. \& Grimm, K. (2015). Early school readiness predictors of grade retention from kindergarten to eight grade: A multilevel discrete-time survival analysis approach. Early Childhood Research Quarterly, 32, 183-192.

De la Calle, A. M., Aguilar, M. \& Navarro, J. (2016). Desarrollo evolutivo de la conciencia fonológica: ¿Cómo se relaciona con la competencia lectora posterior? Revista de Investigación en Logopedia, 1(1), 22-41. 
Defior, S. (2008). ¿Cómo facilitar el aprendizaje inicial de la lectoescritura? Papel de las habilidades fonológicas. Infancia y Aprendizaje, 31, 333-345.

Defior, S. \& Herrera, L. (2003). Les habilités de traitement phonologique des enfants prélecteurs espagnols. In M. N. Rondhane, J. E. Gombert \& M. Belajonza (Eds.), L'aprentissage de la lecture. Perspective comparative interlangue (pp. 161-176). Rennes, France: Presses Universitaires.

Defior, S. \& Serrano, F. (2011). La conciencia fonémica, aliada de la adquisición del lenguaje escrito. Revista de Logopedia, Foniatría y Audiología, 31(1), 2-13.

Dickinson, D. \& Tabors, P. (2001). Beginning literacy with language. Baltimore, MD: Paul H. Brookes.

Dickinson, D. K., McCabe, A., Anastasopoulos, L., Peisner-Feinberg, E. \& Poe, M. D. (2003). The comprehensive language approach to early literacy: The interrelationships among vocabulary, phonological sensitivity, and print knowledge among preschool-aged children. Journal of Educational Psychology, 95(3), 465-481. DOI:10.1037/0022-0663.95.3.465

Diuk, B., Borzone, A. M. \& Ledesma, R. (2010). Conocimiento de vocabulario, representaciones fonológicas y sensibilidad fonológica en niños pequeños de distinto sector social de procedencia. Summa Psicológica, 7(1), 33-50.

Ehri, L., Nunes, S., Willows, D., Schuster, B., Yaghoub-Zadeh, Z. \& Shanahan, T. (2001) Phonemic awareness instruction helps children learn to read: Evidence from the national reading panel's meta-analysis. Reading Research Quarterly, 36(3), 250-287.

Filippetti, V. (2012). Estrato socioeconómico y habilidades cognitivas en niños escolarizados: Variables predictoras y mediadoras. Psylkhe, 21, 3-20.

Foorman, B., Beyler, N., Borradaile, K., Coyne, M., Denton, C. A., Dimino, J., Furgeson, J., Hayes, L., Henke, J., Justice, L., Keating, B., Lewis, W., Sattar, S., Streke, A., Wagnwer, R. \& Wissel, S. (2016). Foundational skills to support reading for understanding in kindergarten through 3rd grade (NCEE 2016-4008). Washington, DC: IES.

Foulin, J. N. (2004). Why is letter-name knowledge such a good predictor of learning to read? Reading and Writing: An Interdisciplinary Journal, 18(2), 129-155.

Georgiou, G., Torppa, M., Manolitsis, G., Lyytinen, H. \& Parrilla, R. (2012). Longitudinal predictors of reading and spelling across languages varying in orthographic consistency. Reading and Writing: An Interdisciplinary Journal, 25, 321-346. 
Gomes-Koban, C., Calet, N. \& Defior, S. (2019). Intervention programs in educational psychology: Bridging research and practice. Anales de Psicología [Annals of Psychology], 35(3), 378-388. DOI:10.6018/analesps.35.3.327941

González, R., López, S., Cuetos, F. \& Vilar, F. (2017). Efectos del entrenamiento en conciencia fonológica y velocidad de denominación sobre la lectura. Un estudio longitudinal. Estudios Sobre Educación, 32, 155-177.

González, R. M., Cuetos, F., Vilar, J. \& Uceira E. (2015). Efectos de la intervención en conciencia fonológica y velocidad de denominación sobre el aprendizaje de la escritura. Aula Abierta, 43(1), 1-8.

Gutiérrez, R. (2016). La lectura dialógica como medio para la mejora de la comprensión lectora. Investigaciones sobre Lectura, 5, 52-58.

Gutiérrez, R. \& Díez, A. (2015). Aprendizaje de la escritura y habilidades de conciencia fonológica en las primeras edades. Bordón, 67(4), 43-59. DOI: 10.13042/bordon.2015.67405

Gutiérrez, F. R. \& Díez, M. A. (2017). Efectos de un programa de conciencia fonológica en el aprendizaje de la lectura y la escritura. Revista Española de Orientación Psicopedagógica, 28(2), 30-45.

Gutiérrez-Fresneda, R., Vicente-Yagüe, M. I. \& Alarcón, R. (2020). Development of the phonological awareness in the beginning of the process of learning to read. Revista Signos. Estudios de Lingüística, 53(104), 664-681. DOI: 10.4067/S0718-09342020000300664

Herrera, L. \& Defior, S. (2005). An approach to the phonological processing in prereading Spanish children: Phonological awareness, verbal short-term memory and naming. Psyche, 14(2), 81-95.

Herrera, L., Defior, S. \& Lorenzo, O. (2007). Intervención educativa en conciencia fonológica en niños prelectores de lengua materna española y Tamazight. Comparación de dos programas de entrenamiento. Infancia y Aprendizaje, 30(1), 39-54.

Hoff, E. (2013). Interpreting the early language trajectories of children from low SES and language minority homes: implications for closing achievement gaps. Developmental Psychology, 49(1), 4-14.

Hulme, C., Bowyer-Crane, C., Carroll, J. M., Duff, F. J. \& Snowling, M. J. (2012). The causal role of phoneme awareness and letter-sound knowledge in learning to read: Combining intervention studies with mediation analyses. Psychological Science, 23(6), 572-577. 
Jasińska, K. \& Laura-Ann, P. (2017). Age of bilingual exposure is related to the contribution of phonological and semantic knowledge to successful reading development. Child Development, 89(1), 310-331.

Jiménez, J. E. \& Ortiz, M. R. (1995). Conciencia fonológica y aprendizaje de la lectura: Teoría, evaluación e intervención. Madrid: Síntesis.

Landerl, K., Freudenthaler, H., Mortiz, H., De Jong, P., Desrochers, A., Manolitsis, G. \& Parrilla, R. (2019). Phonological awareness and rapid automatized naming as longitudinal predictors of reading in five alphabetic orthographies with varying degrees of consistency. Scientific Studies of Reading, 23(3), 220-234.

Letts, C., Edwards, S., Sinka, I., Schafer, B. \& Gibbons, W. (2013). Socio-economic status and language acquisition: children's performance on the new Reynell Developmental Language Scales. International Journal of Language and Communication Disorders, 48(2), 131-143.

Lonigan, C., Schatschneider, C. \& Westberg, L. (2008). Identification of children's skills and abilities linked to later outcomes in reading, writing, and spelling. In National Early Literacy Panel, Developing early literacy: Report of the National Early Literacy Panel (pp. 55-106). Washington, DC: National Institute for Literacy.

Manrique, A. M. \& Gramigna, S. (1985). La segmentación fonológica y silábica en niños de preescolar y primer grado. Lectura y Vida, 5, 4-13.

Mancilla-Martinez, J. \& Lesaux, N. K. (2011). Early home language use and later vocabulary development. Journal of Educational Psychology, 103(3), 535-546. DOI:10.1037/a0023655

Mancilla-Martinez, J. \& Lesaux, N. K. (2017). Early indicators of later english reading comprehension outcomes among children from spanish-speaking homes. Scientific Studies of Reading, 21(5), 428-448. DOI:10.1080/10888438.2017.1320402

Meneses, B. A. L., Garzón, M. A., Macías, J., Argüelles, P. D., Triana, M. C. \& Rodríguez, E. C. (2012). Intervención en conciencia fonológica (CF) en el aula para niños de primer ciclo Cuadernos Hispanoamericanos, 12(2), 65-79.

National Reading Panel (2000). Report of the national reading panel: Teaching children to read (Report No. 00-4769). Washington, DC: NICHHD [on line]. Retrieved from: https://www.nichd.nih.gov/publications/pubs/nrp/smallbook 
Rincón, M. \& Pérez, J. (2009). Programa para el entrenamiento de la conciencia fonológica en niños de 5 a 7 años como prerrequisito para el aprendizaje de la lectura. Revista Areté, 9, 140-150.

Rodríguez, C., Van Der Boer, M., Jiménez, J. \& De Jong, P. (2015). Developmental changes in the relations between RAN, phonological awareness and reading in Spanish children. Scientific Studies of Reading, 19(4), 273-288.

Sattler, J. M. (1992). Assessment of children. The WPPSI-R and WISC-III supplement (3 ${ }^{\text {rd }}$ ed.). Sand Diego, CA: Sattler.

Seymour, P. H. K., Aro, M. \& Erskine, J. M. (2003). Foundation literacy acquisition in European orthographies. British Journal of Psychology, 94(2), 143-174.

Share, D. (2008). On the anglocentricities of current reading research and practice: The perils of overreliance on an outlier orthography. Psychological Bulletin, 134(2), 584-615.

Signorini, A. \& Borzone, A. (2003). Learning to read and spell in Spanish. The prevalence of phonological strategies. Interdisciplinaria, 20(1), 5-30.

Suárez-Coalla, P., García-de-Castro, M. \& Cuetos, F. (2013) Predictors of reading and writing in Spanish. Infancia y Aprendizaje, 36(1), 77-89. DOI:10.1174/021037013804826537

Suggate, S. (2016). A meta-analysis of long-term effects of phonemic awareness, phonics, fluency, and reading comprehension interventions. Journal of Learning Disabilities, 49(1), 77-96. DOI:10.1177/0022219414528540

Suggate, S., Reese E., Lenhard, W. \& Schneider, W. (2014). The relative contributions of vocabulary, decoding and phonemic awareness to word reading in English versus German. Reading and Writing: An Interdisciplinary Journal, 27(8), 13951412. DOI:0.1007/s11145-014-9498-z

United Nations Educational Scientific and Cultural Organization (2019). Education: Repeaters in primary education [on line]. Retrieved from: http://data.uis.unesco.org

Villalón, M. (2008). Procesamiento fonológico y comprensión. In M. Villalón (Ed.), Alfabetización inicial (pp. 92-96). Santiago, Chile: Universidad Católica de Chile.

Wolf, S., Magnuson, K. \& Kimbro, R. (2017). Family poverty and neighborhood poverty: Links with children's school readiness before and after the great recession. Children and Youth Services Review, 79, 368-384.

Woodcock, R. W. \& Muñoz-Sandoval, A. F. (1996). Batería Woodcock-Muñoz: Pruebas de aprovechamiento-Revisada. Itasca, IL: Riverside Publishing. 
Ziegler, J. \& Goswami, U. (2005). Reading acquisition, developmental dyslexia, and skilled reading across languages: A psycholinguistic grain size theory. Psychological Bulletin, 131(1), 3-29. 